\title{
Epidemiological Data - an Important Part of the Hemovigilance System
}

\author{
Ruth Offergeld Osamah Hamouda Reinhard Burger \\ Abteilung für Infektionsepidemiologie, Robert Koch-Institut, Berlin, Germany
}

\author{
Keywords \\ Blood donation $\cdot \mathrm{HBV} \cdot \mathrm{HCV} \cdot$ Hemovigilance $\cdot \mathrm{HIV}$. \\ Epidemiology
}

\section{Summary}

Epidemiological data are essential for monitoring trends and outbreaks of infectious diseases in the general population. The reporting system pursuant to the Infection Protection Act in Germany results in a very good quality of timely nationwide data on all reportable diseases including those relevant for the blood supply: HIV, hepatitis $C$, hepatitis B and syphilis. Notifications of acute hepatitis $B$ and first-time diagnosed hepatitis $C$ infections in the general population showed a declining trend in the past years, but the number of reports of HIV and syphilis infections increased until 2007 especially among men who have sex with men. New preventive strategies should also address changes in sexual behavior. The specific surveillance of blood donors is an important part of the hemovigilance system. The highly effective donor selection process results in a small number of confirmed infections among donors in Germany. The surveillance data enable us to identify specific trends that might challenge blood safety like the increase in HIV infections among repeat donors. Specific evaluations are performed when needed. These additional studies can be used to modify guidelines or recommendations and to (re)evaluate the need for or the effect of further testing.

\author{
Schlüsselwörter \\ Blutspende · HBV · HCV · Hämovigilanz · HIV . \\ Epidemiologie
}

\section{Zusammenfassung}

Infektionsepidemiologische Daten sind wichtig, um Entwicklungen der Infektionsprävalenz und -inzidenz und Häufungen zu identifizieren. Die Überwachung von Infektionskrankheiten gemäß Infektionsschutzgesetz erlaubt in Deutschland eine zeitnahe nationale Erfassung wichtiger Infektionsdaten der Bevölkerung einschließlich solcher Infektionen, die für die Blutsicherheit von Relevanz sind wie HIV, Hepatitis C, Hepatitis B und Syphilis. Die Meldungen von akuten Hepatitis-B- und erstmals diagnostizierten Hepatitis-C-Infektionen in der Allgemeinbevölkerung zeigten in den letzten Jahren einen rückläufigen Trend. Die Anzahl von gemeldeten HIV- und Syphilis-Infektionen hingegen stieg bis zum Jahr 2007 an, vor allem unter Männern, die Sex mit Männern haben. Präventionsmaßnahmen sollen künftig auch das veränderte Sexualverhalten von einigen Hauptbetroffenengruppen berücksichtigen. Die spezifische Überwachung von Blutspendern stellt einen wichtigen Teil des Hämovigilanzsystems dar. Die hocheffektive Spenderauswahl führt dazu, dass nur wenige bestätigte Infektionen unter Spendern in Deutschland diagnostiziert werden. Diese infektionsepidemiologischen Daten dienen dazu, Entwicklungen zu erkennen, die für die Blutsicherheit von Bedeutung sein könnten wie der Anstieg von HIV-Infektionen unter Mehrfachspendern. Ergänzende epidemiologische Studien werden bei Bedarf durchgeführt. Diese Daten können dazu dienen, Empfehlungen oder Richtlinien zu modifizieren und die Notwendigkeit von Screening-Tests zu prüfen.

\section{KARGER}

Fax +497614520714

Information@Karger.de

www.karger.com (c) 2010 S. Karger GmbH, Freiburg

Accessible online at:

www.karger.com/tmh 


\section{Introduction}

The hemovigilance system is a set of surveillance procedures covering the whole transfusion chain (from the collection of blood and its components to the follow-up of recipients) and is intended to collect and assess information on unexpected or adverse effects resulting from the therapeutic use of blood products and to prevent their occurrence or recurrence. The collection of epidemiological data is an important part of this system providing information on the prevalence and incidence of transfusion relevant infections in the donor population. The reporting of adverse effects and epidemiological data is mandatory according to the EU directive on the EU level and pursuant to the Transfusion Act (Transfusionsgesetz) in Germany [1-3]. The data collected on a national level is reported to different international organizations like the World Health Organization (WHO), the Council of Europe and the European Centre for Disease Prevention and Control which facilitates international comparisons. Epidemiological data from blood donors have to be analyzed with care, especially since confirmed infections are rarely diagnosed in this highly selected population. In Germany this task is performed by the Robert Koch Institute (RKI). In order to interpret data from blood donors, the epidemiological situation of the general population of the respective country must be known. In Germany the nationwide mandatory reporting pursuant to the Infection Protection Act (Infektionsschutzgesetz) includes HBV, HCV, HIV and syphilis infections [4].

\section{General Infectious Disease Surveillance}

Surveillance systems for infectious diseases are the basis for effective public health measures in the prevention and control of infectious diseases. In 2001, the new German Infection Protection Act replaced aggregate with individual case reporting. The process was facilitated by the simultaneous introduction of electronic data transfer within the public health system [5]. On the international level EU Member States have had a number of obligations in the area of surveillance and control of communicable diseases since 1999 [6]. In 2005, at a global level, the WHO issued updated International Health Regulations (IHR), which include broader obligations for notification [7].

In Germany the main transfusion-relevant infections HIV, $\mathrm{HCV}, \mathrm{HBV}$ and syphilis are reported on a mandatory basis pursuant to articles 6 and 7 of the Infection Protection Act.

According to article 6 and 7, suspect cases, clinical cases of and deaths from patients with 'acute infective hepatitis' and laboratory diagnosis of HBV and HCV must be reported on a named-patient basis, if the evidence suggests an acute infection. Since it is not readily possible to discriminate between acute and chronic HCV infections, only those HCV infections shall not be reported where chronic infection is known to be present, i.e., those notified already in the past. In order to facilitate this, the reports are limited to first-time diagnosed $\mathrm{HCV}$ infections, regardless whether acute or chronic hepatitis $\mathrm{C}$ infection is present. In contrast, hepatitis B notifications encompass acute hepatitis B only. The notifications of HBV and $\mathrm{HCV}$ infections have to be made to the local health authority within $24 \mathrm{~h}$ after diagnosis so that precautionary measures to prevent further spread of the infection can be initiated. The notifications include demographical data, address of the treating medical facility, previous exposures as a proxy for likely transmission mode and the information whether the patient has donated blood, plasma or organs within the past 6 months. The reports fulfilling the reference definition are then anonymized and forwarded within 14 days via federal state level health authority to the RKI using electronic data transfer. This enables the RKI to analyze trends and to detect outbreaks. In case of an outbreak the RKI can offer assistance to the local health authorities.

Pursuant to article 7 of the Infection Protection Act, any direct or indirect evidence of Treponema pallidum or HIV shall be notified on a non-named-patient basis by the laboratory. These notifications are sent by the diagnosing laboratory directly to the RKI within 14 days. They include demographical data, laboratory results, month and year of the diagnosis and information on the most likely mode of transmission provided by the treating physician (allowing the identification of true cases according to the reference definition). In case of HIV notifications, the HIV reports are additionally coded with an alphanumeric identifier (so-called 'RKI-code' i.e. selected letters of the patients' first and family names) to identify double notifications. If 'transfusion' or 'treatment with blood products' is reported as the most likely mode of transmission, the case is followed up further, if possible, and the physician in charge is asked to report this severe adverse event to the responsible authority, the Paul-Ehrlich-Institute, so that look-back procedures can be initiated.

\section{HIV/AIDS in the General Population}

HIV started to spread in Germany in the late 1970s. The prevalence of HIV rose quickly in groups with a high risk of acquiring an HIV infection, namely among men having sex with men (MSM), i.v. drug users and, in the early 1980s, patients receiving blood or blood products. Mandatory testing of blood donations, effective viral removal steps in the production of plasma derivatives, preventive measures and changes in sexual behavior led to a decline in newly diagnosed infections in the respective groups. In the 1990s the number of newly diagnosed infections remained at a stable level of approximately 2,000/year but between 2000 and 2006 this number rose to a new level of 3,000 newly diagnosed infections/year [8]. The newly acquired infections occur mainly among MSM. In 2008 a total of 2,806 newly diagnosed HIV infections were reported to the RKI. For $85 \%$ of these infections the most likely mode of transmission was specified: $65 \%$ 
of the patients were MSM, heterosexual contacts accounted for $17 \%$ of the newly diagnosed infections, $12 \%$ of the newly diagnosed cases came from high prevalence countries and were probably infected abroad, and $5 \%$ of the patients reported i.v. drug use [9].

The increase of HIV infections among MSM between 2001 and 2007 is most likely due to a combination of risk factors. Preventive strategies among MSM have changed, and the HIV status of a potential sex partner has become more important for the decision if condoms are used or sexual practices are modified (so-called HIV serosorting). Additionally other sexually transmissible diseases (STDs), especially syphilis, have increased. STDs can on one hand increase the chances of becoming infected with HIV and on the other hand lead to an increased infectivity of individuals with HIV due to lesions of mucous membranes [10]. Heterosexual contacts leading to HIV infections were reported for $17 \%$ of patients. This proportion has remained stable in the past 3 years. Two thirds of these HIV infections were most likely acquired in Germany. South East Asia was reported as region where the infection was acquired for $12 \%$ of men in this group, whereas SubSahara Africa was reported for $5 \%$ of men and women in this group. For $5 \%$ of the women the region of infection was Eastern Europe where HIV spreads mainly through i.v. drug use $[11,12]$. Also the knowledge of different risk groups in the different regions of Europe and the world may lead to modifications of the donor selection process.

\section{Syphilis in the General Population}

In 2008 the RKI received 3,172 reports of syphilis infections fulfilling the reference definition. The total number of cases has remained stable since 2004, but there are shifting regional differences due to outbreaks [13]. Only 7\% of all syphilis infections occurred in women, but in regions with outbreaks especially among female sex workers the incidence might be significantly higher than average. In the region of Aachen for instance an increasing incidence of syphilis that can still be identified after 5 years was initially associated with an increase of infections among female sex workers. The vast majority of syphilis infections occur among MSM, especially in urban areas like Berlin, Hamburg, Cologne and Frankfurt/M. Syphilis has reached a new endemic level in some subgroups of MSM with high numbers of sexual partners. The above mentioned HIV serosorting can also contribute to a further spread of syphilis infections if in case of HIV concordance condoms are not used. Public health measures should address the prevention of HIV, syphilis and other STDs in order to react to the changed sexual behavior among some subgroups of MSM.

\section{$H C V$ in the General Population}

In the representative sample of 1998 of the German National Health Survey, the prevalence of antibodies against HCV was found to be $0.4 \%$ (95\% CI $0.2-0.5 \%$ ) [14]. Compared to other, even European countries, Germany has a low HCV prevalence. Still it is estimated that 400,000-500,000 persons carry the virus in Germany. In 2008 6,195 first-time diagnosed $\mathrm{HCV}$ infections were reported to the health authorities, and the declining trend that was observed since 2004 continued [15]. HCV infections are more frequently diagnosed among male than female individuals. This difference is most pronounced in the 25 - to 29 -year-olds. For $71.9 \%$ of all first-time diagnosed $\mathrm{HCV}$ infections in 2008 possible exposures to $\mathrm{HCV}$ were documented. Among these, i.v. drug use (36\%), sexual exposure $(31 \%)$ and invasive medical procedures $(23 \%)$ were reported most often. Intravenous drug use is clearly associated with a risk of acquiring an $\mathrm{HCV}$ infection, and the fact that most i.v. drug users are men contributes greatly to the difference in HCV prevalence between men and women. Surveillance of $\mathrm{HCV}$ infections among i.v. drug users still needs to be improved [16]. Heterosexual transmission of $\mathrm{HCV}$ is possible but not very effective, but there is increasing evidence that HCV transmissions occur among MSM who engage in high-risk activities [17]. This holds especially true for MSM who are co-infected with HIV. Further studies are ongoing to identify specific risk factors and to initiate preventive measures. The high proportion of individuals reporting medical procedures as a possible mode of transmission was due to interventions that dated back many years. The same was true for those 595 individuals who reported having received blood or blood products in the past. Nosocomial HCV infections occur only rarely but need special attention of the health authorities. For instance outbreaks of HCV infections with common features like treatment in a specific medical practice can identify malpractice while handling infusions or syringes.

\section{$H B V$ in the General Population}

In the representative sample of 1998 of the German National Health Survey, the prevalence of antibodies against hepatitis B core antigen $(\mathrm{HBc})$ was found to be $4.3 \%$ in East Germany and $7.7 \%$ in West Germany [14]. The prevalence of hepatitis B surface antigen was $0.6 \%$ (95\% CI $0.4-0.8 \%)$. In 2008, 1,850 notifications of acute $\mathrm{HBV}$ infections were made [15]. Of these only $822(44 \%)$ fulfilled the criteria of the case definition while in the other 1,028 notifications the clinical signs of acute hepatitis B were not met or not reported. The number of reports of acute HBV infections declined in the past years most likely due to better data quality and increasing protection against HBV provided by vaccination in the general public. Men are more often infected with HBV than women, especially men who are 25 years or older. For $83.6 \%$ of all reported infections, exposures possibly leading to infection were reported. The most often reported exposure is sexual contact which is the most likely mode of transmission in Germany $(43.2 \%)$. Medical procedures $(8.3 \%)$, living in one household with a HBV-infected individual $(6.0 \%)$ and i.v. drug use (4.1\%) were reported less frequently. Occupational exposures leading to HBV infection are rare events, and numbers are 
Table 1. Confirmed HIV, HCV, HBV and syphilis infections among blood donors in Germany in 2008

\begin{tabular}{llllc}
\hline Type of donor and number of donors and donations & HIV infections & HCV infections & HBV infections & Syphilis infections \\
\hline New donors $(\mathrm{n}=569,990)$ & 39 & 408 & 780 & 178 \\
$\quad$ Prevalence/100,000 donors & 6.8 & 71.5 & 136.7 & 31.2 \\
Repeat donations/donors $(\mathrm{n}=6,655,053 / 2,376,429)$ & 61 & 53 & 34 & 105 \\
$\quad$ Seroconversions/100,000 donations & 0.9 & 0.8 & 0.5 & 1.6 \\
Incidence/100,000 donors & 2.6 & 2.2 & 1.4 & 4.4 \\
\hline
\end{tabular}

declining continuously. Vaccination has long been recommended for all medical personnel and all other employees dealing with human material [18]. In addition to the vaccination of 'risk groups' the general vaccination of all children has been recommended since 1995. The percentage of children with complete vaccination against HBV increased continuously since 1996, and in 2007 90.2\% of all children entering school had completed the vaccination scheme [19]. This will eventually lead to a further decrease in HBV infections in Germany.

\section{Surveillance among Blood Donors}

Surveillance of the blood donor population is carried out at the RKI pursuant to article 22 of the Transfusion Act and includes HIV, HCV, HBV and syphilis infections [2]. Nationwide data are collected from all blood establishments in Germany regardless of their respective organization. This enables data analysis on a national basis as well as on a regional level. A complementary guideline [20] and a recommendation of the National Advisory Committee 'Blood' [21] define the mode and extend of these reports: Quarterly and yearly reports of the number of donors and donations stratified with respect to age group, sex, type of donation (whole blood, plasma, thrombocytes) and type of donor (first-time donor, repeat or regular donor) separately for each blood establishment have to be reported. Also all confirmed positive HIV, $\mathrm{HCV}, \mathrm{HBV}$ and syphilis infections among donors have to be reported. Additional information such as individual donation history, information on the presumed mode of transmission and detailed laboratory results are available from these donors.

In 2008 more than 550,000 samples of new and applicant blood and plasma donors were screened. Also more than 2.3 million repeat donors were registered who gave more than 6.6 million donations. The prevalence and incidence of the transfusion-relevant infections per 100,000 donors are illustrated in table 1.

The prevalence and incidence of transfusion-relevant infections among donors in Germany is very low. The prevalence of $\mathrm{HCV}$ and $\mathrm{HBV}$ infections among new and applicant donors and the HCV and HBV seroconversions among repeat donors showed a decreasing trend since 2001 [22-24].
Since needle sharing among i.v. drug users bears the highest risk of acquiring an $\mathrm{HCV}$ infection in Germany the donor selection criteria are very effective in reducing the HCV prevalence in the donor population [25]. In addition, with better therapies at hand $\mathrm{HCV}$ infections might have been diagnosed more often by physicians in individuals with a possible exposure in the past rather than diagnosing the infection 'accidentally' while donating blood.

The decrease in HBV infections among donors is most likely a result of ongoing efforts to provide protection by vaccination. Some blood establishments have implemented vaccination programs for donors which can add to transfusion safety. HBV vaccination may even be cost-effective compared to the implementation of additional nucleic acid amplification testing [26]. Still, most prevalent HBV infections in new and applicant donors are detected in the older age groups reflecting the longer time period for exposure to the virus while incident infections among repeat donors occur mainly in the 35to 54-year-old donors. This is consistent with occurrence of acute infections in the general population. Blood establishment have to bear in mind that $\mathrm{HBV}$ is usually transmitted heterosexually in Germany, and special focus in the donor selection process should be made on sexual contact with potentially infected individuals. The surveillance data with respect to HBV infections were supplemented by a recommendation of the National Advisory Committee 'Blood'. According to this recommendation the donors who tested positive for antibodies against $\mathrm{HBc}$ shall be reported to the RKI. These additional reports will enable us to analyze the effect of the antiHBc testing $[27,28]$ on the overall blood safety and the donor pool after implementing the mandatory testing.

While the proportion of syphilis infections did not change in the past years, HIV infections among blood donors, especially repeat donors, showed an increasing trend from 2001 to 2008. To check whether these changes among blood donors only reflect the increasing number of HIV infections in the general population or whether they are due to specific reasons, additional investigations were carried out. A national matched case control study tested the hypothesis that HIVpositive blood donors gave blood more often than HIV-negative donors in order to be tested for HIV (so-called HIV test seeking) and that the HIV test seekers also had relevant risks for acquiring an HIV infection. HIV test seeking is known to be a motivation for giving blood in a subgroup of donors [29, 


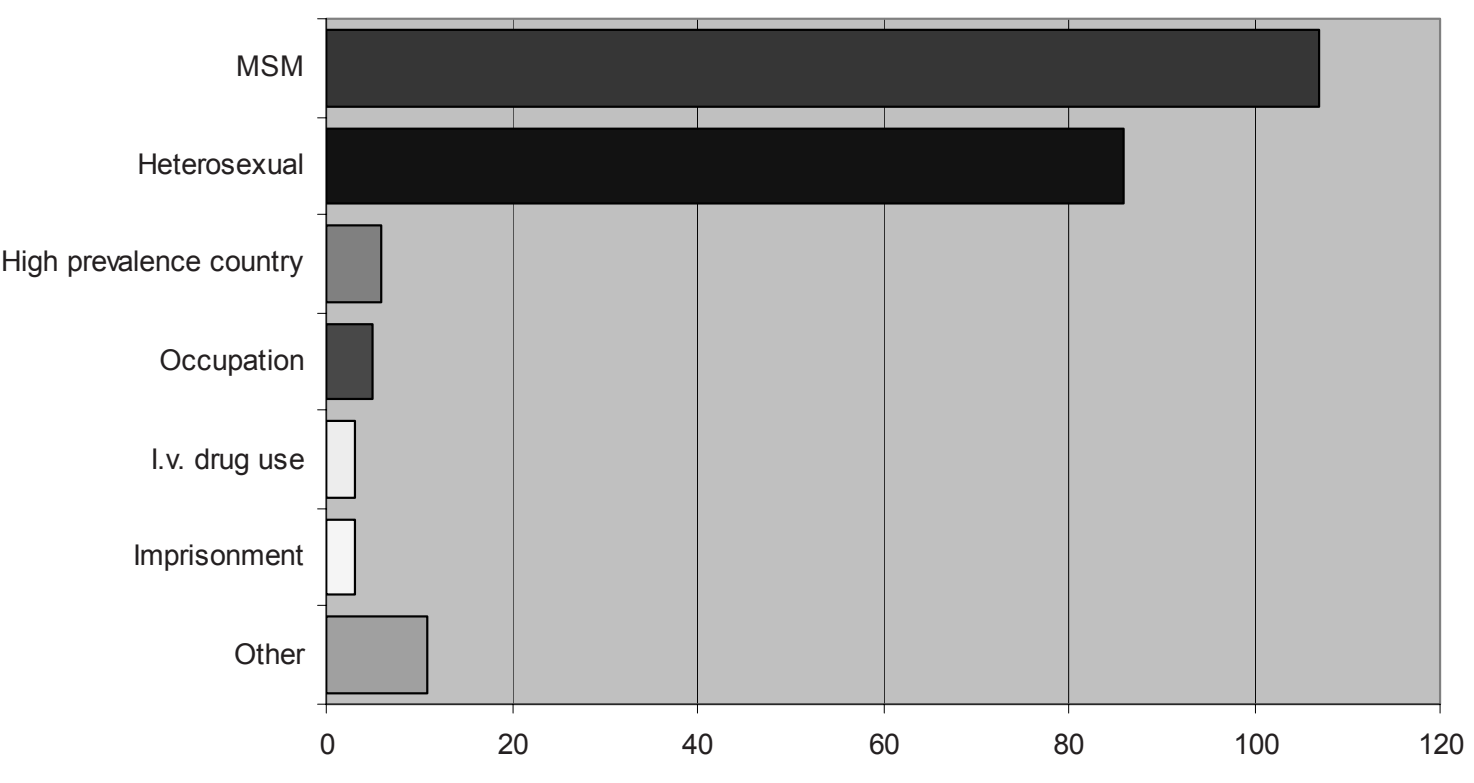

Fig. 1. HIV-positive donors $(\mathrm{n}=221)$ : Most likely mode of infection 2001-2008.

\section{Number of HIV+ donors}

30], but investigations in Norway found that HIV test seekers did not have particulars risks for acquiring an HIV infection [31]. In our study all HIV-positive donors between 2001 and 2005 and matched controls were questioned anonymously about donor motivation, knowledge about donation and infectious diseases and personal risk factors. This study revealed that HIV test seeking was significantly more frequent among the HIV-positive donors. The test seekers in this study admitted (sexual) risk behavior significantly more often than donors who did not quote this motivation for donation. The risk behavior reported most often was sexual contact between men even though according to the German guidelines MSM are permanently deferred from donating blood [25, 32]. Looking at detailed epidemiological data from donors, these findings are supported by the fact that a great proportion of HIVpositive donors admit relevant risk behavior in the post-donation interview. In fact the proportion of MSM in the HIVpositive donor population nearly reflects the proportion of MSM among newly infected HIV-positive individuals in the general population (fig. 1).

There is obviously a number of donors who have unreported deferrable risks, especially MSM, but also donors with heterosexual risk behavior. These donors might give false answers in the donor questionnaire (DQ) and interview because (apart from the desire to receive a test result) they do not fully understand the questions or the need to give such information. They might not accept the donor selection criteria because they consider them to be discriminatory, especially for MSM. The question whether the permanent deferral from blood donation for MSM should be changed to a temporary deferral leading to a better compliance with the deferral criteria and eventually to higher safety of the blood supply has been discussed intensively on an international level [33-35].
Within Europe an expert group coordinated and led by the European Directorate for Quality in Medicine and Health Care (EDQM) is currently investigating the situation and trying to find a consensus on the impact of sexual risk behavior on blood safety.

From our studies we conclude that one measure should be to address HIV test seeking directly in the donor selection process. This is only possible if alternative and free-of-charge HIV testing is available. In order to assure this, the RKI is continuously working with the local health authorities to maintain or even improve this offer in Germany. Nonetheless, the quality of DQs and the information material provided for donors is crucial for a good acceptance of the donor selection criteria. Therefore, efforts were made by a group of experts from the scientific society, the professional organization of physicians in transfusion medicine, and the National Advisory Committee 'Blood'. The group developed a standardized and uniform DQ which focuses on simple, non-medical language, grouped questions, direct assessment of sexual risk behavior and tries to avoid lists (e.g. of diseases) as far as possible. The uniform DQ was tested on 6,500 new donors in four blood establishments of the German Red Cross and one University blood establishment who contributed greatly to the success of the study. Although it will never be possible to identify all previously unreported deferrable risks, the innovative method of testing a DQ on site will lead to results that can help to improve the quality of the donor selection process.

\section{Conclusion}

Epidemiological data of the blood donor population can add to transfusion safety because it facilitates analysis of risk fac- 
tors and trends in the prevalence and incidence of relevant infectious diseases. Also changes in the prevalence and incidence of transfusion-relevant infections in the general population should be observed to interpret trends in the blood donor population correctly. The very good reporting system in Germany for reportable diseases in the general population and the blood donor population represents a stable basis for such analyses. Additional studies like the one on HIV test seeking behavior or on the effect of screening for the presence of anti$\mathrm{HBc}$ can lead to concrete suggestions for the modification of donor selection criteria or recommendations for screening of blood donors even on an international level. The final evaluation of the uniform donor questionnaire will also be of great interest in the near future.

\section{References}

1 Directive 2005/61/EC of the European Parliament and of the Council of 30 September 2005 implementing Directive 2002/98/EC of the European Parliament and of the Council as regards traceability requirements and notification of serious adverse reactions and events. Official J Eur Union 1.10.2005;L 256/32. http://eur-lex.europa.eu/LexUri Serv/LexUriServ.do? uri=OJ:L:2005:256:0032:0040: $E N: P D F$.

2 Gesetz zur Regelung des Transfusionswesens (Transfusionsgesetz) vom 1. Juli 1998 BGBl I:1752.

3 Transfusionsgesetz in der Fassung der Bekanntmachung vom 28. August 2007. BGBl. I, Nr. 45, S. 2169.

4 Gesetz zur Verhütung und Bekämpfung von Infektionskrankheiten beim Menschen (Infektionsschutzgesetz - IfSG) vom 20. Juli 2000, BGBI I: 1045.

$\checkmark 5$ Faensen D, Claus H, Benzler J, Ammon A, Pfoch T, Breuer T, Krause G: SurvNet@RKI a multistate electronic reporting system for communicable diseases. Euro Surveill 2006;11(4):100-103.

6 Decision No 2119/98/EC of the European Parliament and of the Council of 24 September 1998 setting up a network for the epidemiological surveillance and control of communicable diseases in the Community. Official J Eur Union 03.10.1998; L 268/1. http://eur-lex.europa.eu/pri/en/oj/dat/1998/l_ 268/l_26819981003en00010006.pdf.

7 World Health Organization: International Health Regulations. 2005. www.who.int/csr/ihr/wha_58_3/ en/index.html.

8 Robert Koch-Institut: Zum Verlauf der HIV-Epidemie in Deutschland bis Ende 2009. Epid Bull 2009;48:491-492.

9 Robert Koch-Institut: HIV-Infektionen und AIDS-Erkrankungen in Deutschland. Epid Bull 2009;21:203-218.

10 Zetola NM, Klausner JD: Syphilis and HIV infection: An update. CID 2007;44:1222-1228.

11 European Centre for Disease Prevention and Control/WHO Regional Office for Europe: HIV/AIDS Surveillance in Europe 2008. Stockholm, European Centre for Disease Prevention and Control; 2009. DOI 10.2900/26002. www.ecdc.europa.eu/en/publications/Publications/0912_SUR_HIV_AIDS_surveillance_in_Europe.pdf

12 Wiessing L, van de Laar J, Donoghoe MC, Guarita B, Klempová D, Griffiths P: HIV among injecting drug users in Europe: increasing trends in the East. Euro Surveill 2008;13(50):pii = 19067.

13 Robert Koch-Institut. Syphilis in Deutschland im Jahr 2008. Epid Bull 2009;49:503-507.
14 Thierfelder W, Meisel H, Schreier E, Dortschy R: Die Prävalenz von Antikörpern gegen HepatitisA-, Hepatitis-B- und Hepatitis-C-Viren in der deutschen Bevölkerung. Gesundheitswesen 1999; 61:110-114.

15 Robert Koch-Institut: Virushepatitis B, C und D im Jahr 2008. Epid Bull 2009;20:189-199.

16 Wiessing L, Guarita B, Giraudon I, BrummerKorvenkontio H, Salminen M, Cowan SA: European monitoring of notifications of hepatitis $\mathrm{C}$ virus infection in the general population and among injecting drug users (IDUs) - the need to improve quality and comparability. Euro Surveill 2008; 13(21):pii $=18884$

17 Jin F, Prestage GP, Matthews G, Zablotska I, Rawstorne P, Kippax SC, Kaldor JM, Grulich AE: Prevalence, incidence and risk factors for hepatitis $\mathrm{C}$ in homosexual men: data from two cohorts of HIV-negative and HIV-positive men in Sydney, Australia. Sex Transm Infect 2010;86:25-28.

18 Robert Koch-Institut: Empfehlungen der Ständigen Impfkommission (STIKO) am Robert Koch-Institut/Stand: Juli 2009. Epid Bull 2009;30:279-298.

19 Reiter S, Poethko-Müller C: Aktuelle Entwicklung von Impfquoten und Impflücken bei Kindern und Jugendlichen in Deutschland. Bundesgesundheitsbl 2009;52:1037-1044.

20 Verordnung über das Meldewesen nach $\S \S 21$ und 22 des Transfusionsgesetzes (TransfusionsgesetzMeldeverordnung -TFGMV) Bundesgesetzblatt Jg. 2001 und 2005, S. 3737 und S. 234

21 Votum 22 des Arbeitskreises Blut. Empfehlung zum Meldewesen nach Transfusionsgesetz $§ 22$ (Epidemiologische Daten). Bundesgesundheitsbl Gesundheitsforsch Gesundheitsschutz 2004;3:249-252.

22 Willand L, Ritter S, Reinhard B, Offergeld R, Hamouda O: Infektionsepidemiologische Daten von Blutspendern 2006. Bericht des Robert KochInstituts zu den Meldungen nach $\S 22$ Transfusionsgesetz. Bundesgesundheitsbl Gesundheitsforsch Gesundheitsschutz 2008;51:902-914.

23 Offergeld R, Ritter S, Hamouda O: Infektionsepidemiologische Daten von Blutspendern 2005. Bericht des Robert Koch-Instituts zu den Meldungen nach $\S 22$ Transfusionsgesetz. Bundesgesundheitsbl Gesundheitsforsch Gesundheitsschutz 2007;50:1221-1231.

24 Offergeld R, Ritter S, Faensen D, Hamouda O: Infektionsepidemiologische Daten von Blutspendern 2003-2004. Bericht des Robert Koch-Instituts zu den Meldungen nach $\S 22$ Transfusionsgesetz. Bundesgesundheitsbl Gesundheitsforsch Gesundheitsschutz 2005;48:1273-1288.
25 Richtlinien zur Gewinnung von Blut und Blutbestandteilen und zur Anwendung von Blutprodukten (Hämotherapie). Bundesanzeiger. Nr. 92 vom 19.Mai 2007, S. $5075 \mathrm{f}$

26 Ringwald J, Mertz I, Zimmermann R, Weisbach V, Strasser E, Achenbach S, Seyboth S, Richter E, Eckstein R: Hepatitis B virus vaccination of blood donors - what costs may be expected? Transfus Med 2005;15:83-92.

27 Bescheid des Paul-Ehrlich-Instituts: Abwehr von Arzneimittelrisiken; Testung auf Antikörper gegen Hepatitis-B-Core-Antigen (anti-HBc) im Blutspendewesen (vom 08. Mai 2006) Bundesanzeiger Nr. 109 vom 13. Juni 2006, S. 4370.

28 Mitteilungen des Arbeitskreises Blut des Bundesministeriums für Gesundheit und Soziale $\mathrm{Si}$ cherung. Erhöhung der Sicherheit von zellulären Blutkomponenten und quarantäne-gelagertem Frischplasma durch Untersuchung der Blut- und Plasmaspenden auf Antikörper gegen das Hepa titis-BCore-Antigen (Anti-HBc). Bundesgesundheitsbl Gesundheitsforsch Gesundheitsschutz 2005;48:698-699.

29 Damesyn MA, Glynn SA, Schreiber GB, Ownby HE, Bethel J, Fridey J, McMullen Q, Garratty G, Busch MP, for the NHLBI Retrovirus Epidemiology Donor Study: Behavioral and infectious disease risks in young blood donors: implications for recruitment. Transfusion 2003;43:1596-1603.

30 Glynn SA, Kleinman SH, Schreiber GB, et al: Motivations to donate blood: demographic comparisons. Transfusion 2002;42:216-225.

31 Stigum H, Bosnes V, Magnus P, Orjasaeter H: Risk behaviour among blood donors who give blood in order to be tested for the human immmunodeficiency virus. Vox Sang 2001;80:24-27.

32 Offergeld R, Guigard A, Ritter S, Hamouda O Blood donor motivation and HIV test seeking in Germany. Transfus Med Hemother 2008;35(suppl 1):33 (abstr.).

33 Soldan K, Sinka K: Evaluation of the de-selection of men who have had sex with men from blood donation in England. Vox Sang 2003;84:265-273.

34 Leiss W, Tyshenko M, Krewski D: Men having sex with men donor deferral risk assessment: an analysis using risk management principles. Transfus Med Rev 2008;22:35-57.

35 Vamvakas EC: Why are all men who have had sex with men even once since 1977 indefinitely deferred from donating blood? Transfusion 2009;49: 1037-1042. 